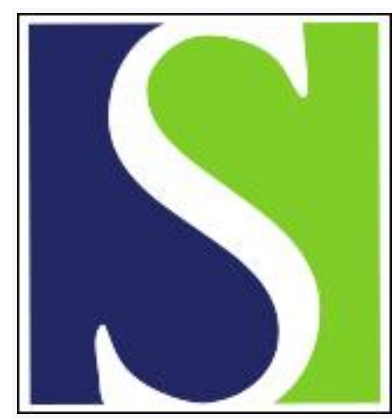

Scand J Work Environ Health 2006;32(3):178-184

https://doi.org/10.5271/sjweh.996

Issue date: 30 Jun 2006

Brain tumors and occupational exposures in a cohort of female textile workers in Shanghai, China

by Gold LS, De Roos AJ, Ray RM, Wernli K, Fitzgibbons ED, Gao D-L, Astrakianakis G, Feng Z, Thomas D, Checkoway H

Affiliation: Program in Epidemiology, Fred Hutchinson Cancer Research Center, 1100 Fairview Ave. N. PO Box 19024 Seattle, WA 98109, USA.

Key terms: brain tumor; case-cohort study; China; female; maintenance; occupational exposure; textile industry; textile worker; wool

This article in PubMed: www.ncbi.nlm.nih.gov/pubmed/16804619

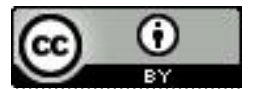




\title{
Brain tumors and occupational exposures in a cohort of female textile workers in Shanghai, China
}

\author{
by Laura S Gold, MSPH, ${ }^{1,2}$ Anneclaire J De Roos, PhD, ${ }^{1,2}$ Roberta M Ray, MS, ${ }^{1}$ Karen Wernli, MS, ${ }^{1,2}$ \\ E Dawn Fitzgibbons, MPH, ${ }^{1}$ Dao-Li Gao, MD, ${ }^{4}$ George Astrakianakis, PhD, ${ }^{3}$ Ziding Feng, PhD, ${ }^{5}$ \\ David Thomas, MD, ${ }^{1,2}$ Harvey Checkoway, PhD ${ }^{2,3}$
}

\begin{abstract}
Gold LS, De Roos AJ, Ray RM, Wernli K, Fitzgibbons ED, Gao D-L, Astrakianakis G, Feng Z, Thomas D, Checkoway $\mathrm{H}$. Brain tumors and occupational exposures in a cohort of female textile workers in Shanghai, China. Scand J Work Environ Health 2006;32(3):178-184.
\end{abstract}

\begin{abstract}
Objectives This study assessed the associations between brain tumors and specific processes and exposures among female textile workers in Shanghai, China.

Methods A case-cohort study was conducted that was nested in a cohort of textile workers originally included in a randomized trial of breast self-examination. Incident brain tumor cases $(\mathrm{N}=114)$ were identified from 1989 to 1998 from a tumor and death registry operated by the Shanghai Textile Industry Bureau. A subcohort $(\mathrm{N}=3188)$, representing an age-stratified random sample of the entire cohort, was selected as a comparison group. Job-exposure matrices were created to assess historical exposures to specific agents, including quantitative assessments for cotton dust and endotoxin exposure. Cox proportional hazards modeling, modified according to a case-cohort design, was used to analyze associations between jobs and exposures and the risk of brain tumors.

Results Employment in maintenance workshops was associated with an increased brain tumor incidence (evernever exposed hazard ratio $2.36,95 \%$ confidence interval 1.12-4.97), with increasing hazard ratios by duration of employment in maintenance jobs. Handling or processing wool fibers was associated with an increased risk of brain tumors, as was specific exposure to wool fibers; however, estimates did not increase with duration of employment.
\end{abstract}

Conclusions These results provide some preliminary suggestion that employment in textile industry maintenance jobs and exposure to wool products may be associated with an increased risk of brain tumors.

Key terms case-cohort study; maintenance; textile industry; wool.

Although brain tumors are rarely diagnosed, the 5-year survival rates of adults are low (less than $25 \%$ for people diagnosed after 45 years of age), and, therefore, the importance of identifying risk factors is high (1). The etiologies of brain tumors are not well understood, although associations with some occupations and occupational exposures have been reported. Several studies have observed an increased risk of brain tumors in association with work in the textile industry (2-7), although no specific causative agents have been identi- fied. Studies of other industries have found associations between brain tumors and several exposures commonly encountered in the textile industry, including electromagnetic fields (EMF) [see Kheifets (8) and Ahlbom (9) for reviews], solvents $(10-12)$, metals $(10,13,14)$, and lubricants (15-17).

While past studies focused on a broad array of industries, our research focused solely on the textile industry. By linking job histories with cancer registry data in a large, previously established cohort of female

\author{
Program in Epidemiology, Fred Hutchinson Cancer Research Center, Seattle, Washington, United States. \\ Department of Epidemiology, University of Washington, Seattle, Washington, United States. \\ Department of Environmental and Occupational Health Sciences, University of Washington, Seattle, Washington, \\ United States. \\ Department of Epidemiology, Zhong Shan Hospital Cancer Center, Shanghai, People's Republic of China. \\ Program in Cancer Prevention, Fred Hutchinson Cancer Research Center, Seattle, Washington, United States.
}

Reprint requests to: Dr A De Roos, Fred Hutchinson Cancer Research Center, Seattle, WA 98109-1024, USA. [E-mail: aderoos@fhcrc.org] 
textile workers in Shanghai, China, we were able to examine specific textile industry processes and exposures and evaluate their relation to brain tumors.

\section{Study population and methods}

The study population was derived from 267400 women employed in 526 factories of the Shanghai Textile Industry Bureau (STIB) who were originally enrolled in a randomized trial of breast self-examination in 19891991 in Shanghai, China $(18,19)$. At enrollment, the women were administered a questionnaire eliciting data on demographic characteristics, smoking and alcohol habits, and reproductive history. The study was approved by the institutional review boards of the Station for Prevention and Treatment of Cancer of the STIB and the Fred Hutchinson Cancer Research Center.

For this study of textile industry exposures and brain tumors, we used a case-cohort design nested within the original randomized trial. A subcohort of 3188 workers was selected. This number was chosen because it was about twice as many persons as the largest group of cancer cases (1507 cases of breast cancer), and it allowed us to have adequate statistical power to perform analyses for multiple cancer sites. The subcohort was selected after the case status was known, but without regard to case status. Members of the subcohort formed a randomized sample of the whole cohort, stratified into 5year age groups, with the sampling fraction for each age group such that the age distribution of the subcohort approximated the age distribution of all of the cases combined.

Current and retired workers received routine health care through their factory health clinics. Tumor incidence was determined from 1989 to 1998 from medical reports submitted by individual factories to a tumor and death registry operated by the STIB. Case finding was supplemented by manual review of the records of the Shanghai Cancer Registry (SCR) (19). As further verification of identified cases, STIB records were reviewed to determine the basis for diagnosis, and brain cancers occurring following metastases from other sites $(\mathrm{N}=8)$ were excluded. Fifty cases were not matched in the SCR, but $27(54 \%)$ of them were confirmed by STIB medical staff. A basis for diagnosis was not available for 15 cases. Following these reviews, all primary brain tumors [International Classification of Diseases (ICD), 9th revision codes 191, 192.2, 194.3, 225, 348.0, 348.8; $\mathrm{N}=114]$ identified in the cohort were selected for the present case-cohort study; four of the cases were coincidentally also selected for the subcohort.

Data on employment period, workplace, task descriptions, and changes in jobs for each woman were abstracted from factory personnel records by trained field workers, and women whose data were not available for abstraction (9\%) were interviewed directly. Most $(85 \%)$ of the women in the subcohort had worked in only one or two factories over their entire careers (18).

In addition, information on the primary fibers used in the factories, manufacturing processes, and the occurrence of hazardous exposures (chemical uses, biological and physical exposures) were assessed in China by trained industrial hygienists. Nine sectors of fiber type were defined [cotton, cotton-synthetic, cotton-other fiber (not synthetic), wool, silk, synthetic fibers, mineral, other mixed fiber, and none] and specific processes that occurred in each sector were grouped by a team of occupational hygiene experts. Each woman's work history was linked by process groupings to a specially developed job-exposure matrix (JEM) that classified likely exposures in jobs and processes according to the following agents: electromagnetic fields, cotton dusts, synthetic fiber dusts, lubricants, wool, solvents, acids, bases, and caustics, metals, and endotoxin (Wernli et al, in submission). Textile industry processes and specific exposures were coded as ever ( $\geq 1$ year) versus never ( $<1$ year) exposed and were also categorized by number of years of exposure (never, $<10$ years, 10-20 years, $\geq 20$ years).

Quantitative estimates of exposures to cotton dust and bacterial endotoxin were estimated for specific jobs from historical cotton dust measurements available from factory inspection reports. The cumulative exposure to endotoxin for the case-cohort study participants was approximated on the basis of the estimated cotton dust levels and previously published data regarding specific endotoxin per unit dust in textile processes (20-24). $\mathrm{Cu}$ mulative exposure was then categorized into quartiles among those who were ever exposed, on the basis of the subcohort's exposure distribution. The cotton dust estimates for six specific processes in two factories over four time periods were validated using independently collected measurement data (24). Women who worked as machinists, in wool production, or as sanitation workers were excluded from the endotoxin analyses because these processes may have entailed exposures to endotoxin from sources other than cotton.

The risk of brain tumor associated with each job process in the textile industry and specific exposure was estimated using a weighting scheme for the stratified case-cohort design (25), using Stata version 8.0 (Stata Corporation, College Station, TX, USA). Hazard ratios (HR) and 95\% confidence intervals $(95 \% \mathrm{CI})$ were calculated using Cox proportional hazard methods with robust variance estimates (26). The cases and subcohort members contributed person-time to the analysis beginning with their dates of enrollment into the study until the dates of diagnosis (all cases, including cases from the subcohort) or the end of follow-up (subcohort 
noncase members). The participants who were selected for the subcohort but also developed brain tumors contributed person-time to the subcohort group until immediately preceding the diagnosis date, at which time they were censored. The participants who died $(\mathrm{N}=181$, $5.6 \%)$ or left the STIB (N=96, 3.0\%) prior to $31 \mathrm{De}-$ cember 1998 were censored at date of death or departure from the industry. All cases received a one-unit weight, and the controls were weighted by the inverse of their sampling probabilities. Therefore, this weighting scheme mimicked the analysis that would have taken place had data for the whole cohort been available, and it was consistent with the sampling plan of the study design. Additional analyses were conducted when exposures were lagged by 10 and 20 years to account for the potential latency of carcinogenesis. All of the analyses were adjusted for age. We also compared frequencies of various demographic and lifestyle factors between the cases and noncases to evaluate possible confounding of textile industry exposure-brain tumor associations and further examined whether such factors

Table 1. Distribution of the cases and a subcohort of noncases according to demographic factors, smoking, alcohol use, and reproductive history.

\begin{tabular}{|c|c|c|c|c|}
\hline \multirow[t]{2}{*}{ Characteristic } & \multicolumn{2}{|c|}{ Cases $(N=114)$} & \multicolumn{2}{|c|}{ Noncases $(\mathrm{N}=3184)$} \\
\hline & N & $\%$ & $\mathrm{~N}$ & $\%$ \\
\hline \multicolumn{5}{|l|}{ Age } \\
\hline 30-34 years & 8 & 7.0 & 177 & 5.6 \\
\hline $35-39$ years & 16 & 14.0 & 302 & 9.5 \\
\hline $40-44$ years & 4 & 3.5 & 297 & 9.3 \\
\hline $45-49$ years & 6 & 5.3 & 166 & 5.2 \\
\hline 50-54 years & 14 & 12.3 & 317 & 10.0 \\
\hline $55-59$ years & 31 & 27.2 & 863 & 27.1 \\
\hline 60-64 years & 28 & 24.6 & 964 & 30.3 \\
\hline $65-69$ years & 7 & 6.1 & 98 & 3.1 \\
\hline \multicolumn{5}{|l|}{ Marital status } \\
\hline Never married & 0 & 0 & 29 & 0.9 \\
\hline Ever married & 114 & 100 & 3155 & 99.1 \\
\hline \multicolumn{5}{|l|}{ Smoking status } \\
\hline Never & 108 & 94.7 & 3039 & 95.5 \\
\hline Ever & 6 & 5.3 & 145 & 4.5 \\
\hline \multicolumn{5}{|c|}{ Alcohol consumption } \\
\hline Never & 92 & 80.7 & 2608 & 81.9 \\
\hline$<1$ drink/month & 15 & 13.2 & 433 & 13.6 \\
\hline$\geq 1$ drink/month & 7 & 6.1 & 143 & 4.5 \\
\hline \multicolumn{5}{|l|}{ Live births } \\
\hline 0 & 0 & 0 & 124 & 3.9 \\
\hline 1 & 32 & 29.6 & 750 & 23.6 \\
\hline 2 & 20 & 18.5 & 572 & 18.0 \\
\hline$>2$ & 56 & 51.8 & 1738 & 54.6 \\
\hline \multicolumn{5}{|l|}{ Postmenopausal } \\
\hline Yes & 78 & 68.4 & 2196 & 69.1 \\
\hline No & 36 & 31.6 & 984 & 30.9 \\
\hline \multicolumn{5}{|l|}{ Hysterectomy } \\
\hline Yes & 10 & 8.8 & 127 & 4.0 \\
\hline No & 104 & 91.2 & 3053 & 96.0 \\
\hline
\end{tabular}

were confounders by adjustment in multivariable models. Finally, to assess the consistency of our results, we performed analyses excluding the 15 brain tumor cases for which a basis for diagnosis was not available. Because these analyses did not differ from those that included all of the cases, we present results from analyses on all 114 brain tumor cases.

\section{Results}

The cases and noncases were similar in age distribution, marital status, smoking, alcohol consumption, parity, and menopausal status (table 1). Proportionately more cases $(9 \%)$ than noncases (4\%) had a history of hysterectomy $(\mathrm{P}=0.01)$. None of the demographic factors listed in table 1 importantly affected the hazard ratios for the occupational processes and exposures; therefore, all of the models were adjusted only for age (design variable). A comparison of demographic factors between the subcohort and the entire cohort revealed that they were similar in terms of smoking status and alcohol consumption (27).

Risks associated with involvement in a variety of textile industry processes are shown in table 2. Employment in maintenance jobs was positively associated with brain tumor incidence, and the association increased with greater time involved with the process ( $\mathrm{P}$ trend $=0.04$ ). The risk estimate was statistically significant when all of the participants who were ever employed in maintenance workshops were compared with those who were not (data not shown in tables: HR 2.36, 95\% CI 1.12-4.97). Increased risks were found for handling, processing, or spinning wool fibers for less than 10 years and 10 to 20 years, but the risk did not increase by duration of work with wool fibers, and few cases were exposed in high-duration categories. An analysis comparing ever to never handling, processing, or spinning wool fibers indicated an elevated but not significant relative risk (data not shown in tables: HR 2.00, 95\% CI 0.90-4.46). Analyses of exposures with 10- and 20 -year lag times revealed no meaningful changes in the risk estimates for any of the textile industry processes.

The associations of specific exposures incurred from textile industry processes with brain tumors are presented in table 3. Exposure to wool for 10-20 years was associated with brain tumors, whereas exposure for $<10$ or $>20$ years was not, and no significant association was observed for having ever been exposed to wool (data not shown in tables: HR 1.32, 95\% CI 0.80-2.17). Analyses of exposures with 10- and 20-year lag times revealed inverse associations for women exposed to lubricants, electromagnetic fields, or synthetic fiber dust for at least 20 years, the statistically significant risk 
Table 2. Age-adjusted hazard ratios (HR) with $95 \%$ confidence intervals $(95 \% \mathrm{Cl})$ for the association between brain tumors and textile industry processes according to the duration of involvement in the processes.

\begin{tabular}{|c|c|c|c|c|c|}
\hline Job process ${ }^{a}$ & $\begin{array}{l}\text { Cases } \\
(\mathrm{N}=114)\end{array}$ & $\begin{array}{l}\text { Noncases } \\
(\mathrm{N}=3184)\end{array}$ & $H R$ & $95 \% \mathrm{Cl}$ & P-trend \\
\hline \multicolumn{6}{|c|}{ Cotton fibers-material handling, fiber processing, spinning } \\
\hline $\begin{array}{l}\text { Never } \\
<10 \text { years } \\
10-20 \text { years } \\
>20 \text { years }\end{array}$ & $\begin{array}{r}94 \\
5 \\
1 \\
14\end{array}$ & $\begin{array}{r}2588 \\
122 \\
154 \\
320\end{array}$ & $\begin{array}{r}1 \\
1.12 \\
0.17 \\
1.15\end{array}$ & $\begin{array}{c}\cdot \\
0.45-2.78 \\
0.02-1.25 \\
0.65-2.03\end{array}$ & $\begin{array}{r}\dot{ } \\
0.92\end{array}$ \\
\hline \multicolumn{6}{|c|}{ Mixed fibers-material handling, fiber processing, spinning } \\
\hline $\begin{array}{l}\text { Never } \\
<10 \text { years } \\
10-20 \text { years } \\
>20 \text { years }\end{array}$ & $\begin{array}{r}98 \\
4 \\
4 \\
8\end{array}$ & $\begin{array}{r}2741 \\
126 \\
115 \\
202\end{array}$ & $\begin{array}{r}1 \\
0.90 \\
0.99 \\
1.12\end{array}$ & $\begin{array}{c}\cdot \\
0.32-2.50 \\
0.36-2.74 \\
0.54-2.34\end{array}$ & $\dot{.}$. \\
\hline \multicolumn{6}{|c|}{ Wool fibers-material handling, fiber processing, spinning } \\
\hline $\begin{array}{l}\text { Never } \\
<10 \text { years } \\
10-20 \text { years } \\
>20 \text { years }\end{array}$ & $\begin{array}{r}107 \\
3 \\
2 \\
2\end{array}$ & $\begin{array}{r}3082 \\
20 \\
28 \\
54\end{array}$ & $\begin{array}{r}1 \\
4.16 \\
2.05 \\
1.06\end{array}$ & $\begin{array}{c}\cdot \\
1.21-14.3 \\
0.48-8.76 \\
0.25-4.43\end{array}$ & $\begin{array}{r}\dot{ } \\
\dot{\cdot} \\
0.57\end{array}$ \\
\hline \multicolumn{6}{|l|}{ Weaving } \\
\hline $\begin{array}{l}\text { Never } \\
<10 \text { years } \\
10-20 \text { years } \\
>20 \text { years }\end{array}$ & $\begin{array}{r}77 \\
12 \\
7 \\
18\end{array}$ & $\begin{array}{r}2065 \\
231 \\
295 \\
593\end{array}$ & $\begin{array}{r}1 \\
1.47 \\
0.63 \\
0.83\end{array}$ & $\begin{array}{c}\cdot \\
0.79-2.74 \\
0.29-1.39 \\
0.49-1.41\end{array}$ & $\begin{array}{r}\dot{ } \\
0.31\end{array}$ \\
\hline \multicolumn{6}{|c|}{ Cutting or sewing } \\
\hline $\begin{array}{l}\text { Never } \\
<10 \text { years } \\
10-20 \text { years } \\
>20 \text { years }\end{array}$ & $\begin{array}{r}101 \\
5 \\
4 \\
4\end{array}$ & $\begin{array}{r}2889 \\
87 \\
96 \\
112\end{array}$ & $\begin{array}{r}1 \\
1.66 \\
1.22 \\
1.05\end{array}$ & $\begin{array}{c}\cdot \\
0.66-4.18 \\
0.44-3.39 \\
0.38-2.92\end{array}$ & $\begin{array}{r}\dot{\cdot} \\
\dot{\cdot} \\
0.71\end{array}$ \\
\hline \multicolumn{6}{|c|}{ Warehouse packing and quality control } \\
\hline $\begin{array}{l}\text { Never } \\
<10 \text { years } \\
10-20 \text { years } \\
>20 \text { years }\end{array}$ & $\begin{array}{r}97 \\
7 \\
7 \\
3\end{array}$ & $\begin{array}{r}2664 \\
182 \\
148 \\
190\end{array}$ & $\begin{array}{r}1 \\
1.06 \\
1.29 \\
0.44\end{array}$ & $\begin{array}{c}\cdot \\
0.48-2.31 \\
0.59-2.84 \\
0.14-1.40\end{array}$ & $\begin{array}{r}\dot{ } \\
\dot{ } \\
0.30\end{array}$ \\
\hline \multicolumn{6}{|l|}{ Maintenance } \\
\hline $\begin{array}{l}\text { Never } \\
<10 \text { years } \\
10-20 \text { years } \\
>20 \text { years }\end{array}$ & $\begin{array}{r}106 \\
3 \\
2 \\
3\end{array}$ & $\begin{array}{r}3078 \\
48 \\
27 \\
31\end{array}$ & $\begin{array}{r}1 \\
1.87 \\
2.12 \\
2.79\end{array}$ & $\begin{array}{c}\cdot \\
0.57-6.10 \\
0.50-9.00 \\
0.84-9.30\end{array}$ & $\begin{array}{r}\dot{.} \\
0.04\end{array}$ \\
\hline \multicolumn{6}{|c|}{ Administration or nonproduction } \\
\hline $\begin{array}{l}\text { Never } \\
<10 \text { years } \\
10-20 \text { years } \\
>20 \text { years }\end{array}$ & $\begin{array}{l}79 \\
12 \\
13 \\
10\end{array}$ & $\begin{array}{r}2277 \\
339 \\
266 \\
302\end{array}$ & $\begin{array}{r}1 \\
1.05 \\
1.40 \\
0.96\end{array}$ & $\begin{array}{c}\cdot \\
0.55-1.97 \\
0.76-2.58 \\
0.49-1.88\end{array}$ & $\begin{array}{r}\dot{.} \\
\dot{.} \\
0.75\end{array}$ \\
\hline
\end{tabular}

a Only processes with at least five exposed cases are presented.

estimates ranging from 0.4 to 0.5 (results not shown in tables).

The quantitative estimates of exposures to cotton dust and endotoxin were not consistently associated with brain tumors (table 4). Somewhat inverse risk gradients were observed for cumulative exposures to cotton dust and to endotoxin with a 20-year lag, but neither the risk estimates nor the tests of trend were statistically significant.

\section{Discussion}

The duration of employment in maintenance jobs was related to an increased risk of brain tumors. Exposure
Table 3. Age-adjusted hazard ratios (HR) with the 95\% confidence intervals $(95 \% \mathrm{Cl})$ for the association between brain tumors and textile industry exposures according to the duration of the exposures. (EMF = electromagnetic fields)

\begin{tabular}{|c|c|c|c|c|c|}
\hline Exposure $^{a}$ & $\begin{array}{c}\text { Cases } \\
(\mathrm{N}=114)\end{array}$ & $\begin{array}{l}\text { Noncases } \\
(\mathrm{N}=3184)\end{array}$ & HR & $95 \% \mathrm{Cl}$ & P-trend \\
\hline \multicolumn{6}{|l|}{ EMF } \\
\hline Never & 38 & 1016 & 1 & . & . \\
\hline$<10$ years & 14 & 344 & 1.12 & $0.60-2.10$ & . \\
\hline $10-20$ years & 18 & 576 & 0.84 & $0.47-1.48$ & . \\
\hline$>20$ years & 44 & 1248 & 0.95 & $0.61-1.49$ & 0.71 \\
\hline \multicolumn{6}{|l|}{ Lubricants } \\
\hline Never & 47 & 1210 & 1 & $\cdot$ & . \\
\hline$<10$ years & 11 & 331 & 0.89 & $0.46-1.74$ & . \\
\hline $10-20$ years & 16 & 495 & 0.82 & $0.46-1.47$ & . \\
\hline$>20$ years & 40 & 1148 & 0.89 & $0.58-1.38$ & 0.62 \\
\hline \multicolumn{6}{|c|}{ Synthetic fiber dust } \\
\hline Never & 69 & 1919 & 1 & . & . \\
\hline$<10$ years & 10 & 238 & 1.21 & $0.61-2.37$ & . \\
\hline 10-20 years & 14 & 362 & 1.04 & $0.58-1.86$ & . \\
\hline$>20$ years & 21 & 665 & 0.91 & $0.55-1.49$ & 0.71 \\
\hline \multicolumn{6}{|l|}{ Wool } \\
\hline Never & 94 & 2734 & 1 & 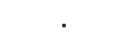 & . \\
\hline$<10$ years & 3 & 94 & 0.92 & $0.28-2.97$ & . \\
\hline $10-20$ years & 9 & 111 & 2.36 & $1.16-4.80$ & . \\
\hline$>20$ years & 8 & 245 & 0.96 & $0.46-2.00$ & 0.42 \\
\hline \multicolumn{6}{|l|}{ Solvents } \\
\hline Never & 98 & 2726 & 1 & 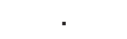 & . \\
\hline$<10$ years & 5 & 169 & 0.81 & $0.32-2.04$ & . \\
\hline $10-20$ years & 7 & 139 & 1.31 & $0.59-2.91$ & . \\
\hline$>20$ years & 4 & 150 & 0.73 & $0.27-2.03$ & 0.80 \\
\hline \multicolumn{6}{|c|}{ Acids, bases \& caustics } \\
\hline Never & 107 & 2921 & 1 & . & . \\
\hline$<10$ years & 1 & 90 & 0.28 & $0.04-2.10$ & . \\
\hline $10-20$ years & 4 & 86 & 1.17 & $0.42-3.29$ & . \\
\hline$>20$ years & 2 & 87 & 0.63 & $0.15-2.60$ & 0.57 \\
\hline \multicolumn{6}{|l|}{ Metals } \\
\hline Never & 104 & 2958 & 1 & 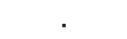 & . \\
\hline$<10$ years & 3 & 87 & 0.98 & $0.30-3.17$ & . \\
\hline $10-20$ years & 4 & 57 & 1.86 & $0.66-5.23$ & . \\
\hline$>20$ years & 3 & 82 & 1.06 & $0.33-3.42$ & 0.56 \\
\hline
\end{tabular}

a Only agents with at least five exposed cases are presented.

to wool fibers was also associated with brain tumors, but the risk did not increase by duration of employment.

According to our job process groupings, the women employed in maintenance workshops in this study were involved in electrical welding, metal works, carpentry, painting, and waste water processing. These jobs potentially entailed exposures to metals, lubricants, solvents, or natural fibers. In an examination of these specific exposures, as assigned by the job-exposure matrix, only exposure to metals showed a somewhat positive association with brain tumors. Lead, included in our metals category of exposure, has been implicated as a risk factor for brain cancer (13), and other studies have found an increased risk of brain cancer for machinists, precision metal workers, welders, and metal cutters $(10,14$, $15,28)$. Our findings should be interpreted with caution, 
Table 4. Age-adjusted hazard ratios (HR) with the 95\% confidence intervals $(95 \% \mathrm{CI})$ for the associations between brain tumors and estimated cumulative quantitative cotton dust and endotoxin exposures. ${ }^{\text {a }}$

\begin{tabular}{lccc}
\hline Dust exposure & $\begin{array}{c}\text { Cases } \\
(\mathrm{N}=114)\end{array}$ & $\begin{array}{c}\text { Non- } \\
\text { cases } \\
(\mathrm{N}=3184)\end{array}$
\end{tabular} HR $\quad 95 \% \mathrm{Cl}$ P-trend ${ }^{\mathrm{b}}$

Endotoxina $\left(E U / m^{3} \times\right.$ years $)-$ no lag

$\begin{array}{llllll}0 & 30 & 916 & 1.00 & \text { reference } & \\ >0 \text { to } 1517.35 & 25 & 530 & 1.38 & 0.80-2.39 & \\ >1517.35 \text { to } 2429.97 & 16 & 529 & 0.90 & 0.49-1.67 & \\ >2429.97 \text { to } 3530.63 & 19 & 530 & 1.08 & 0.60-1.93 & \\ >3530.63 & 17 & 530 & 0.95 & 0.52-1.72 & 0.65\end{array}$

Endotoxina $\left(E U / \mathrm{m}^{3} \times\right.$ years $)-10$ years lag

\begin{tabular}{lccccc}
0 & 31 & 926 & 1.00 & reference & \\
$>0$ to 1517.35 & 27 & 628 & 1.22 & $0.70-2.11$ & \\
$>1517.35$ to 2429.97 & 16 & 500 & 0.94 & $0.51-1.72$ & \\
$>2429.97$ to 3530.63 & 17 & 480 & 1.04 & $0.57-1.88$ & \\
$>3530.63$ & 16 & 501 & 0.92 & $0.50-1.68$ & 0.65 \\
Endotoxin (EU/m $\times$ years) & -20 years lag & & & \\
0 & 39 & 1093 & 1.00 & reference & \\
$>0$ to 1517.35 & 29 & 665 & 1.17 & $0.72-1.91$ & \\
$>1517.35$ to 2429.97 & 14 & 462 & 0.83 & $0.45-1.54$ & \\
$>2429.97$ to 3530.63 & 14 & 401 & 0.94 & $0.50-1.75$ & \\
$>3530.63$ & 11 & 414 & 0.69 & $0.35-1.36$ & 0.22 \\
Cotton dust $\left(\mathrm{mg} / \mathrm{m}^{3} \times\right.$ years) $)$ no lag & & & \\
0 & 33 & 1016 & 1.00 & reference & \\
$>0$ to 55.85 & 26 & 541 & 1.43 & $0.84-2.43$ & \\
$>55.85$ to 96.98 & 11 & 543 & 0.61 & $0.30-1.21$ & \\
$>96.98$ to 143.42 & 21 & 542 & 1.20 & $0.76-2.23$ & \\
$>143.42$ & 23 & 542 & 1.30 & $0.76-2.23$ & 0.62 \\
Cotton dust $\left(\mathrm{mg} / \mathrm{m}^{3} \times\right.$ years) $)-10$ years lag & & & \\
0 & 34 & 1026 & 1.00 & reference & \\
$>0$ to 55.85 & 29 & 611 & 1.36 & $0.80-2.31$ & \\
$>55.85$ to 96.98 & 10 & 520 & 0.57 & $0.28-1.16$ & \\
$>96.98$ to 143.42 & 20 & 511 & 1.18 & $0.67-2.06$ & \\
$>143.42$ & 21 & 516 & 1.21 & $0.70-2.10$ & 0.70 \\
Cotton dust $\left(\mathrm{mg} / \mathrm{m}^{3} \times\right.$ years) & -20 years lag & & & \\
0 & 43 & 1198 & 1.00 & reference & \\
$>0$ to 55.85 & 27 & 638 & 1.13 & $0.69-1.85$ & \\
$>55.85$ to 96.98 & 15 & 456 & 0.92 & $0.50-1.68$ & \\
$>96.98$ to 143.42 & 15 & 457 & 0.90 & $0.49-1.65$ & \\
$>143.42$ & 14 & 435 & 0.87 & $0.47-1.60$ & 0.53 \\
\hline
\end{tabular}

a Women with jobs in sanitation or wool production and machinists were not included in the analysis.

${ }^{b}$ Trend test across the median of fourths, among the exposed only.

however, since they are based on small numbers of exposed cases, and an increasing time of exposure to metals was not related to a greater risk of brain tumors in our data.

We observed increases in brain tumor risk when we analyzed employment processes involving wool, as well as for wool exposure as assigned by the job-exposure matrix; however, no positive trend was observed for increasing lengths of time exposed to wool products. Several previous studies have identified associations between brain tumors and exposure to wool products, although the evidence is somewhat inconsistent. McLaughlin et al (28) found that women employed in the wool industry in Sweden were at a significantly in- creased risk of brain tumors. Preston-Martin et al (29) reported that working with sheep (and thereby presumed to be exposed to wool) was significantly associated with brain tumors among men in New Zealand. In contrast, Menegoz (30) did not detect an association between contact with sheep and the risk of brain tumors. Possible explanations for a relation with wool exposure are unclear, although employment in wool processing has been shown to cause infectious disease (31-33), and infectious etiologies for brain tumors have been hypothesized $(34,35)$.

Exposure to endotoxin has been hypothesized to be related to a decreased risk of lung cancer (36-39), perhaps by activation of the immune system with macrophage surveillance and increased secretion of cytokines such as TNF- $\alpha$ (tumor necrosis factor) (40). However, to our knowledge, an apparently protective effect of endotoxin with a relation to brain tumor risk has not been previously reported. Our observation of a slightly decreased risk with increasing endotoxin exposure was only observed when exposures were lagged by 20 years, and it was not statistically significant. Future studies investigating this relationship should be conducted.

When exposures to textile industry processes were lagged for 10 and 20 years, the women exposed to lubricants, electromagnetic fields, or synthetic fiber dusts for at least 20 years were at decreased risk of brain tumors. We did not have a priori biological reasons for suspecting protective effects of these exposures for brain tumors. We hypothesize that these observations may be the result of a healthy worker survivor effect, as women in the 20-year exposure categories lagged by 20 years had longer total employment in the industry than women of similar ages in the lower-duration exposure categories, possibly indicating that they were in better overall health (41).

Previous studies of textile employment and brain tumors were population-based case-control studies that were not designed specifically to investigate exposures in the textile industry $(2,4-7)$. Our study had the advantage of focusing on specific exposures and job processes, and compared textile workers to each other, rather than to workers employed in other occupations. In addition, since we assigned exposures based on factory records of each woman's work history, the exposure status was not prone to recall bias.

This study did have several limitations, however. Many exposures and processes had small numbers of exposed persons and, therefore, led to statistically imprecise risk estimates. The possibility of our findings being due to chance cannot be ruled out. Although all of the brain tumor cases in our study were verified through a cancer registry or medical records, information on tumor histology was not readily available for most of the cases. Because the causes of brain tumors 
may differ by type (42-44), exposure-disease associations that are specific to certain tumor types may have been obscured in our analyses. Finally, it is possible that we did not observe positive associations by increasing the duration of exposure because the less healthy workers may have left jobs with harmful exposures before they had time to develop brain tumors.

Our findings indicate that future investigations on brain tumors should examine exposures involved in maintenance work, such as lubricants, solvents, and metals. Our findings also support prior evidence that exposures to wool products increase the risk of brain tumors, despite the absence of clear pathogenic mechanisms.

\section{Acknowledgments}

This work was supported by grant R01CA80180 from the National Cancer Institution and training grant T32ES07262 from the National Institute of Environmental Health Sciences in the United States.

The authors thank Drs Fan Liang Chen, Yong Wei Hu, Lei Dan Pan, Guan Lin Zhao, and Wen Wan Wang for their assistance with the study planning, data collection, and project management; Dai He-Liang, Wang Zhu Ming, Qi A-Zhen, Wang Xia Ming, Xiang Wei Ping, and Li Yu Fang for their extensive efforts in collecting factory information; Dr Wenjin Li for the translation and review of the medical records; and Shirley Zhang and Ted Grichuhin for programming support.

\section{References}

1. National Cancer Institute. Surveillance epidemiology and end results: SEER*Stat Database: Incidence-SEER 9 Regs Public-Use. Bethesda (MD): National Cancer Institute; 2005.

2. Carozza SE, Wrensch M, Miike R, Newman B, Olshan AF, Savitz DA, et al. Occupation and adult gliomas. Am J Epidemiol. 2000;152(9):838-46.

3. Pan SY, Ugnat AM, Mao Y. Occupational risk factors for brain cancer in Canada. J Occup Environ Med. 2005; 47(7):704-17.

4. Zheng T, Cantor KP, Zhang Y, Keim S, Lynch CF. Occupational risk factors for brain cancer: a population-based casecontrol study in Iowa. J Occup Environ Med. 2001;43(4):31724.

5. Kaplan S, Etlin S, Novikov I, Modan B. Occupational risks for the development of brain tumors. Am J Ind Med. 1997;31(1):15-20.

6. Cocco P, Dosemeci M, Heineman EF. Occupational risk factors for cancer of the central nervous system: a case-control study on death certificates from 24 U.S. states. Am J Ind Med. 1998;33(3):247-55.

7. Heineman EF, Gao YT, Dosemeci M, McLaughlin JK. Occu- pational risk factors for brain tumors among women in Shanghai, China. J Occup Environ Med. 1995;37(3):288-93.

8. Kheifets LI, Afifi AA, Buffler PA, Zhang ZW. Occupational electric and magnetic field exposure and brain cancer: a metaanalysis. J Occup Environ Med. 1995;37(12):1327-41.

9. Ahlbom IC, Cardis E, Green A, Linet M, Savitz D, Swerdlow A. Review of the epidemiologic literature on EMF and Health. Environ Health Perspect. 2001;109 suppl 6:911-33.

10. Rodvall Y, Ahlbom A, Spannare B, Nise G. Glioma and occupational exposure in Sweden, a case-control study. Occup Environ Med. 1996;53(8):526-37.

11. Heineman EF, Cocco P, Gomez MR, Dosemeci M, Stewart PA, Hayes RB et al. Occupational exposure to chlorinated aliphatic hydrocarbons and risk of astrocytic brain cancer. Am J Ind Med. 1994;26(2):155-69.

12. Park RM, Silverstein MA, Green MA, Mirer FE. Brain cancer mortality at a manufacturer of aerospace electromechanical systems. Am J Ind Med. 1990;17(5):537-52.

13. Cocco P, Dosemeci M, Heineman EF. Brain cancer and occupational exposure to lead. J Occup Environ Med. 1998;40(11):937-42.

14. Preston-Martin S, Mack W, Henderson BE. Risk factors for gliomas and meningiomas in males in Los Angeles County. Cancer Res. 1989;49(21):6137-43.

15. Thomas TL, Fontham ET, Norman SA, Stemhagen A, Hoover RN. Occupational risk factors for brain tumors: a case-referent death-certificate analysis. Scand J Work Environ Health. 1986;12(2):121-7.

16. Tsai SP, Wendt JK, Cardarelli KM, Fraser AE. A mortality and morbidity study of refinery and petrochemical employees in Louisiana. Occup Environ Med. 2003;60(9):627-33.

17. Wesseling C, Pukkala E, Neuvonen K, Kauppinen T, Boffetta $\mathrm{P}$, Partanen T. Cancer of the brain and nervous system and occupational exposures in Finnish women. J Occup Environ Med. 2002;44(7):663-8.

18. Camp JE, Seixas NS, Wernli K, Fitzgibbons D, Astrakianakis G, Thomas DB, et al. Development of a cancer research study in the Shanghai textile industry. Int J Occup Environ Health 2003;9(4):347-56.

19. Wernli KJ, Ray RM, Gao DL, Thomas DB, Checkoway H. Cancer among women textile workers in Shanghai, China: overall incidence patterns, 1989-1998. Am J Ind Med. 2003;44(6):595-9.

20. Christiani DC, Wegman DH, Eisen EA, Ye TT, Lu PL, Olenchock SA. Cotton dust and gram-negative bacterial endotoxin correlations in two cotton textile mills. Am J Ind Med. 1993;23(2):333-42.

21. Christiani DC, Ye TT, Zhang S, Wegman DH, Eisen EA, Ryan LA et al. Cotton dust and endotoxin exposure and longterm decline in lung function: results of a longitudinal study. Am J Ind Med. 1999;35(4):321-31.

22. Olenchock SA, Christiani DC, Mull JC, Ye TT, Lu PL. Endotoxins in baled cottons and airborne dusts in textile mills in the People's Republic of China. Appl Environ Microbiol. 1983;46(4):817-20.

23. Olenchock SA, Christiani DC, Mull JC, Ye TT, Lu PL. Airborne endotoxin concentrations in various work areas within two cotton textile mills in the People's Republic of China. Biomed Environ Sci. 1990;3(4):443-51.

24. Astrakianakis G, Seixas NS, Camp JE, Christiani DC, Feng Z, Thomas DB, et al. Modeling, estimation and validation of cotton dust and endotoxin exposures in Chinese textile operations. Ann Occup Hyg. In press.

25. Borgan O, Langholz B, Samuelsen SO, Goldstein L, Pogoda 
J. Exposure stratified case-cohort designs. Lifetime Data Anal. 2000;6(1):39-58.

26. Barlow WE. Robust variance estimation for the case-cohort design. Biometrics. 1994;50(4):1064-72.

27. Thomas DB, Gao DL, Ray RM, Wang WW, Allison CJ, Chen FL, et al. Randomized trial of breast self-examination in Shanghai: final results. J Natl Cancer Inst. 2002;94(19):144557.

28. McLaughlin JK, Malker HS, Blot WJ, Malker BK, Stone BJ, Weiner JA, et al. Occupational risks for intracranial gliomas in Sweden. J Natl Cancer Inst. 1987;78(2):253-7.

29. Preston-Martin S, Lewis S, Winkelmann R, Borman B, Auld J, Pearce N. Descriptive epidemiology of primary cancer of the brain, cranial nerves, and cranial meninges in New Zealand, 1948-88. Cancer Causes Control. 1993;4(6):529-38.

30. Menegoz F, Little J, Colonna M, Arslan A, Preston-Martin S, Schlehofer B, et al. Contacts with animals and humans as risk factors for adult brain tumours: an international case-control study. Eur J Cancer. 2002;38(5):696-704.

31. Plotkin SA, Brachman PS, Utell M, Bumford FH, Atchison MM. An epidemic of inhalation anthrax, the first in the twentieth century, I: clinical features: 1960. Am J Med 2002;112(1):4-12.

32. Rehacek J. Epidemiology and significance of Q fever in Czechoslovakia. Zentralbl Bakteriol Mikrobiol Hyg [A]. 1987;267(1):16-9.

33. Weber DJ, Rutala WA. Zoonotic infections. Occup Med. 1999;14(2):247-84.

34. Copeland DD, Vogel FS, Bigner DD. The induction of intractranial neoplasms by the inoculation of avian sarcoma virus in perinatal and adult rats. J Neuropathol Exp Neurol. 1975;34(4):340-58.

35. Berleur MP, Cordier S. The role of chemical, physical, or viral exposures and health factors in neurocarcinogenesis: implications for epidemiologic studies of brain tumors. Can- cer Causes Control. 1995;6(3):240-56.

36. Lange JH, Mastrangelo G, Fedeli U, Rylander R, Christiani DC. There is an alternative reason for lower-than-expected rates of lung cancer in farmers. Arch Environ Health. 2003;58(5):316-7.

37. Mastrangelo G, Fedeli U, Fadda E, Milan G, Lange JH. Epidemiologic evidence of cancer risk in textile industry workers: a review and update. Toxicol Ind Health. 2002;18(4):17181.

38. Lange JH. Reduced cancer rates in agricultural workers: a benefit of environmental and occupational endotoxin exposure. Med Hypotheses. 2000;55(5):383-5.

39. Mastrangelo G, Marzia V, Marcer G. Reduced lung cancer mortality in dairy farmers: is endotoxin exposure the key factor? Am J Ind Med. 1996;30(5):601-9.

40. Rylander R. Endotoxin in the environment-exposure and effects. J Endotoxin Res. 2002;8(4):241-52.

41. Steenland K, Deddens J, Salvan A, Stayner L. Negative bias in exposure-response trends in occupational studies: modeling the healthy workers survivor effect. Am J Epidemiol. 1996;143(2):202-10.

42. Rajaraman P, De Roos AJ, Stewart PA, Linet MS, Fine HA, Shapiro WR, et al. Occupation and risk of meningioma and acoustic neuroma in the United States. Am J Ind Med. 2004;45(5):395-407.

43. Navas-Acien A, Pollan M, Gustavsson P, Plato N. Occupation, exposure to chemicals and risk of gliomas and meningiomas in Sweden. Am J Ind Med. 2002;42(3):214-27.

44. De Roos AJ, Stewart PA, Linet MS, Heineman EF, Dosemeci $\mathrm{M}$, Wilcosky T, et al. Occupation and the risk of adult glioma in the United States. Cancer Causes Control. 2003;14(2):139 50.

Received for publication: 10 May 2005 